\title{
透析患者における血中フルクトサミン值についての検討
}

\author{
野村 佳成 南條 輝志男* 角谷 佳城 別所 寛人 \\ 佐々木 秀行* 大星 隆司 雑賀 博子** 藤井 良一** \\ 宮 村 敬* \\ 公立尾崎病院内科 和歌山県立医科大学第 1 内科 * 藤井病院内科 ** \\ (昭和 63 年 11 月 7 日受付)
}

key words：フルクトサミン值, 血糖コントロール, 慢性腎不全透析症例, 糖尿病性腎症, ヘパリンの影響

〈要旨〉

糖尿病性腎症 23 名を含む慢性腎不全透析症例 48 例より透析前後に採血し, 血清（S）および血漿（P) フルクトサ ミン值 (Fr) を測定し以下の成績を得た。 1 ) 透析前後とも, S-Fr に比し EDTA-2Na 採血後測定された P-Fr は有意 の低值を示したが, 両者の間に有意の正相関が認められた. 2 )S-Fr, P-Fr とも透析前後の值に差異は認められなかっ た. 弚の一因に, 透析前に比し除水により高值となった透析後の Fr が, 透析中に添加された heparin の影響により, 測定法上，低下をきたしたことが考えられる。また，透析前の S-Fr において，3）糖尿病性腎症の S-Fr は非糖尿 病性腎不全症例に比し高值を示した。4)S-Fr は, 同時測定された血糖值よりも過去 2 週間の平均透析前血糖値 ( $\overline{P G})$ との方が相関性が強く, affinity chromatography 法による glycated albumin and $\mathrm{Hb}$ 值や $\mathrm{HbA}_{1}$ and $\mathrm{HbA}_{1 \mathrm{c}}$ 值とも 有意の正相関を示した。しかし, 尿素窒素, 尿酸, クレアチニン, アセト酢酸, 3 ヒドロキシ酪酸などの各値とは相 関性を示さなかった。 5 ) $\overline{\mathrm{PG}}$ は, S-Fr/総蛋白の A/G ratio >S-Fr/アルブミン值 $>S-F r>S-F r /$ 総蛋白值, の順に強 い有意の正相関を示した. 従って, Fr の測定は糖尿病を含む慢性腎不全透析症例における過去 2 週間の長期的な血糖 コントロール状態の指標として有用であることが実証された。 また, S-Fr を総蛋白の A/G ratio により除すことに より, S-Fr のみ, またはアルブミン值により除す Fr 補正值に比し, $\overline{P G}$ との相関がより一層強くなることが示唆さ れた。 さらに, 一回の血液透析過程が Fr に及ぼす影響としては, 主として透析中に添加される heparin が, 測定法 上，透析後の Fr の低下をきたすことも分かった。

\section{Fructosamine concentration in serum and plasma of hemodialyzed patients with chronic renal failure}

Yoshinari Nomura M. D., Kishio Nanjo M. D.*, Yoshiki Kadoya M. D., Hiroto Bessho M. D., Hideyuki Sasaki M. D. ${ }^{*}$, Takashi Ohoshi M. D., Hiroko Saiga M. D. ${ }^{* *}$, Ryoichi Fujii M. D. ${ }^{* *}$, Kei Miyamura M. D.* Department of Medicine, Ozaki Public Hospital. First Department of Medicine, Wakayama University of Medical Science*. Department of Medicine, Fujii Hospital**.

Blood samples were drawn before and after hemodialysis (HD) from 48 patients with chronic renal failure, including 23 patients with diabetic nephropathy, to measure fructosamine concentration ( $\mathrm{Fr}$ ) in serum (S) and plasma (P). The results obtained were as follows : 1) P-Fr with EDTA-2Na was found to be significantly lower than S-Fr. However, a significant positive correlation was recognized between P-Fr and S-Fr. 2) For both S-Fr and $\mathrm{P}-\mathrm{Fr}$, no significant difference was observed between $\mathrm{Fr}$ before and after HD. It seems that the addition of heparin during HD led to a reduction in Fr after HD, although $\mathrm{Fr}$ was higher after HD than before HD due to water loss. 3) An increased S-Fr before HD was recognized in hemodialyzed patients with diabetic nephropathy compared with those without diabetes. 4) S-Fr showed a closer correlation with mean values of plasma glucose before HD during the last 2 weeks $(\overline{\mathrm{PG}})$ than plasma glucose values measured simultaneously. Significant positive correlations were shown between S-Fr and glycated albumin, glycated hemoglobin, $\mathrm{HbA}_{1}$ and $\mathrm{HbA}_{1 \mathrm{c}}$. However, no

野村 佳成 公立尾崎病院内科

干 599-02 大阪府泉南郡阪南町下出 17(0724-71-3321) significant correlation was recognized between S-Fr and concentrations of urea nitrogen, uric acid, 
creatinine, acetoacetic acid and 3-hydroxybutyrate.

5) $\overline{\mathrm{PG}}$ showed the following positive correlations, the S-Fr/A/G ratio of total protein $>\mathrm{S}-\mathrm{Fr} /$ albumin value $>$ $\mathrm{S}-\mathrm{Fr}>\mathrm{S}-\mathrm{Fr}$ /total protein value (in decreasing order of strength).

Determination of $\mathrm{Fr}$, therefore, proved useful as an indicator for the control of glucose levels during the last 2 weeks in hemodialyzed patients with chronic renal failure, including those with diabetes mellitus. $\overline{P G}$ demonstrated a closer correlation with the level of the S-Fr/A/G ratio than S-Fr only or the correct value for Fr obtained by dividing $\mathrm{Fr}$ by albumin value. Moreover, in terms of the effect of each $\mathrm{HD}$ on $\mathrm{Fr}$, it was clarified that the addition of heparin during HD leads to a reduction in $\mathrm{Fr}$ after HD.

\section{緒言}

1982 年, Johnson ら ${ }^{1)}$ は, 血中の糖化蛋白をアルカリ 溶液中において nitroblue tetrazolium と反応させ, 発 色した formazan を定量することによりフルクトサミン 值 $(\mathrm{Fr})$ として測定することに成功し，翌年，Baker ら ${ }^{2)}$ は, 糖尿病患者における $1 \sim 3$ 週間の血糖コントロール 状態の指標としての Fr 測定の臨床的有用性を報告し た。また, 最近では Fr を autoanalyzerにより, 短時 間に，しかも簡便に測定可能となったことにより ${ }^{3,4)}$, 日 常の臨床検査に取り入れられつつある.

現在, 糖尿病患者における Fr 測定についての報告は 多数見られるようになってきたが5,6), 慢性腎不全透析患 者についての臨床的検討は未だ少ないように思われる。 今回, 糖尿病性腎症を含む慢性腎不全透析症例において 血清 (S) および血漿 (P) Fr を測定し, 一回の血液透析 過程が Fr に及ぼす影響を検索するとともに, 過去 2 週 間の長期的な血糖コントロール状態の指標としての有用 性を検討した。

\section{対象と方法}

糖尿病性腎症 23 名 (インスリン治療群 7 名, 経口血糖 降下剂治療群 2 名, 食事療法群 14 名) を含む慢性腎不全 透析症例 48 名において透析前 (即ち, 朝食 2 時間後) と 透析後に, 健常者 17 名においては朝食 2 時間後に採血 し，Fr を測定するとともに以下の検索に供した。なお， 透析症例のうち過去 2 週間の平均透析前血糖值 $(\overline{\mathrm{PG}})$ が $120 \mathrm{mg} / \mathrm{d} l$ 以上の者は 27 名, $120 \mathrm{mg} / \mathrm{d} l$ 以下の者は 21 名であった。

1. 普通管と EDTA-2Na 管に採血され測定された $\mathrm{S}$ -Fr と P-Fr について, 透析前 $(\mathrm{n}=48)$, 透析後 $(\mathrm{n}=28)$ において両者を比較するとともに, その相関関係を調べ た.また，抗凝固剤 (heparin, EDTA-2Na) の Frへの 影響を調べるため, 健常者より heparin 採血, EDTA$2 \mathrm{Na}$ 採血, または heparin 採血後 EDTA-2Na 管内に 保存し, 各々の P-Fr を duplicate にて測定し S-Fr と 比較した。

2. 血液透析過程の Frへの影響を調べるため, 同一 症例 $(\mathrm{n}=28)$ の S-Fr, P-Fr について, 透析前後におけ

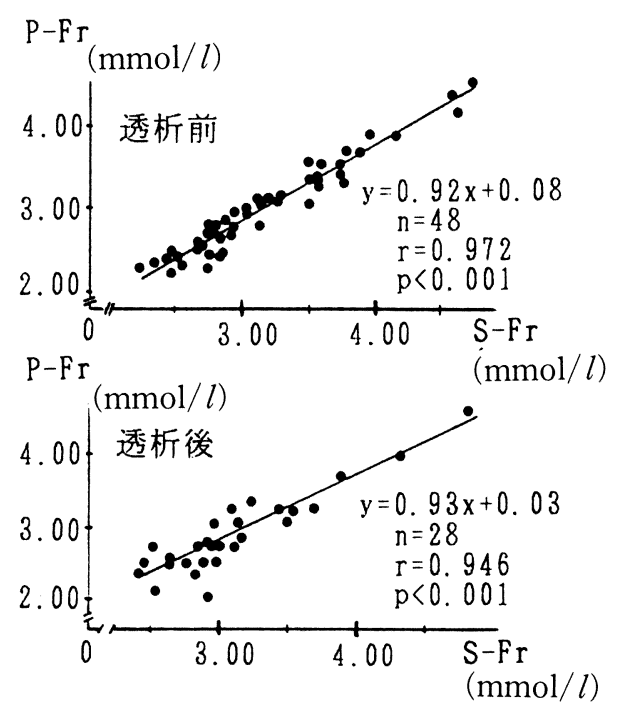

図 1 透析前, 透析後における血清 (S) と血漿 (P) フルクトサミン值 $(\mathrm{Fr})$ との相関関係

る両者の比較を行った．ただし，上記の透析後に採血さ れた血液には血液透析中に付加された heparin が混和さ れている。

また，透析前の S-Fr について，

3. 慢性腎不全透析症例を原因疾患により糖尿病性腎 症 $(n=23)$ と非糖尿病性腎不全 $(n=25)$ の 2 群に分類 し, 両群における S-Fr を比較した。 また, 透析症例の うち, $\overline{\mathrm{PG}}$ が $120 \mathrm{mg} / \mathrm{d} l$ 以上の群, $\overline{\mathrm{PG}}$ が $120 \mathrm{mg} / \mathrm{d} l$ 以 下の群, ならびに健常者の 3 群において S-Fr を比較し た.

4. S-Fr と, 同時採血した透析前血糖值 (PG-ST) や $\overline{\mathrm{PG}}$ との間の相関関係を調べるとともに, glycated albu$\min$ (G. Alb), glycated hemoglobin (G. $\mathrm{Hb}), \mathrm{HbA}_{1}$, $\mathrm{HbA}_{1 \mathrm{c}}$ の各值との相関関係も検索した。また, $\overline{\mathrm{PG}}$ が 120 $\mathrm{mg} / \mathrm{d} l$ 以下の透析群において, S-Fr と同時測定した尿 素窒素 (BUN), 尿酸 (UA), クレアチニン $(\mathrm{Cr})$, アセト 酷酸 $(\mathrm{AA}), 3-$ 一ドロキシ酪酸 $(3 \mathrm{HB})$, コレステロール (Chol), HDL-コレステロール (HDL), 中性脂肪 (TG) 


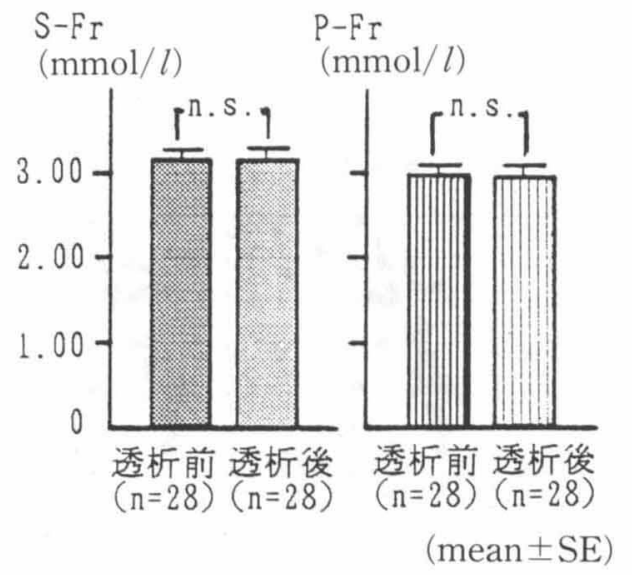

図 2 透析前後の血清 (S) または血獎 $(\mathrm{P})$ フル クトサミン值 $(\mathrm{Fr})$ の比較

の各值，ならびに BUN, UA, Cr については透析前にお ける過去 2 週間の平均值 $(\overline{\mathrm{BUN}}, \overline{\mathrm{UA}}, \overline{\mathrm{Cr}})$ と, S-Fr と の相関関係も調べた.

5. S-Fr と同時測定した透析前血糖値 (PG-ST), 過 去 1,2 週間の平均透析前血糖值 $(\overline{\mathrm{PG}}-1 \mathrm{~W}, \overline{\mathrm{PG}})$ と, S-Fr, $\mathrm{S}-\mathrm{Fr} /$ 総蛋白值 (S-Fr/Pro), S-Fr/アルブミン值 ( $\mathrm{S}$ -Fr/Alb), S-Fr/総蛋白の A/G ratio (S-Fr/AGR) との 相関関係を検索した.

なお，Fr はフルクトサミン測定キット（日本ロシュ, 東京）を用いて Cobas Mira により, G. Alb と G. Hb 值は Glyc-Affin System (Isolab, Ohio) と Glyc-Affin $\mathrm{GHb}$ キット (生化学工業, 東京) を用いて affinity chromatography 法により, $\mathrm{HbA}_{1 \mathrm{c}}, \mathrm{HbA}_{1}$ 值はイオン 交換樹脂を用いた HPLC 法 (HA-8110 ; 京都第一科学, 京都)により測定した. 結果は mean $\pm \mathrm{SE}$ で示す.また, 透析症例のアルブミン值は $3.3 \sim 5.2 \mathrm{~g} / \mathrm{d} l$, 総蛋白值は 5.9 $\sim 8.0 \mathrm{~g} / \mathrm{d} l$, 総蛋白の $\mathrm{A} / \mathrm{G}$ ratio は $0.97 \sim 2.46$ の範囲で あった。

\section{結果}

1. S-Fr, P-Fr は各々, 透析前 $(\mathrm{n}=48) ; 3.19 \pm 0.09$, $3.02 \pm 0.08 \mathrm{mmol} / l$, 透析後 $(\mathrm{n}=28) ; 3.18 \pm 0.12,2.98 \pm 0$. $12 \mathrm{mmol} / l$ と S-Fr に比し P-Fr の方が低值を呈した $(\mathrm{p}<0.01)$ 。また, 透析前後とも $\mathrm{S}-\mathrm{Fr}$ と $\mathrm{P}-\mathrm{Fr}$ との間に 有意の正相関（透析前； $\mathrm{n}=48, \mathrm{r}=0.972, \mathrm{p}<0.001$, 透析 後; $\mathrm{n}=28, \mathrm{r}=0.946, \mathrm{p}<0.001$ ) を認めた（図 1). 健常 者血の S-Fr $(2.43 \mathrm{mmol} / l)$ に比し, Heparin 採血, EDTA-2Na 採血の $\mathrm{P}-\mathrm{Fr}$ は各々 $2.27 \mathrm{mmol} / l, 2.26$ $\mathrm{mmol} / l$ と低值を示し, Heparin 採血後 EDTA-2Na 管 内に保存した検体では $2.16 \mathrm{mmol} / l$ とより一層の低下を 示した.

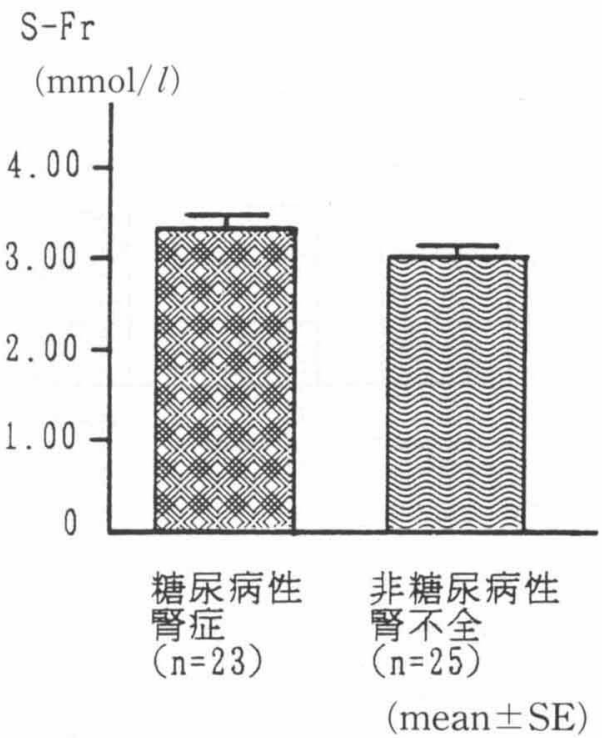

図 3 糖尿病性腎症と非糖尿病性腎不全群におけ る血清フルクトサミン值 (S-Fr) の比較

2. 透析前後における S-Fr は各久, $3.19 \pm 0.10,3.18 \pm$ $0.12 \mathrm{mmol} / l, \mathrm{P}-\mathrm{Fr}$ は各々, $2.99 \pm 0.10,2.98 \pm 0.12 \mathrm{mmol} /$ $l$ と透析前後の Fr に有意の差異は認めなかった (図 2 ).

3 . 糖尿病性腎症群の $\mathrm{S}-\mathrm{Fr}(3.33 \pm 0.15 \mathrm{mmol} / \mathrm{l})$ は非 糖尿病性腎不全群 $(3.05 \pm 0.09 \mathrm{mmol} / l)$ に比し高值を示 した (図 3 )。また, $\overline{\mathrm{PG}}$ が $120 \mathrm{mg} / \mathrm{d} l$ 以上の透析群 ( $\overline{\mathrm{PG}}$ $176 \pm 10 \mathrm{mg} / \mathrm{d} l)$ の S-Fr $(3.51 \pm 0.11 \mathrm{mmol} / l)$ は $\overline{\mathrm{PG}}$ が $120 \mathrm{mg} / \mathrm{d} l$ 以下の透析群 $(\mathrm{S}-\mathrm{Fr} 2.77 \pm 0.08 \mathrm{mmol} / l, \overline{\mathrm{PG}}$ $101 \pm 2 \mathrm{mg} / \mathrm{d} l$ ) や健常者群 (S-Fr $2.71 \pm 0.06 \mathrm{mmol} / l$, $\overline{\mathrm{PG}} 98 \pm 3 \mathrm{mg} / \mathrm{d} l$ ) に比し有意の高值を示したものの, $\overline{\mathrm{PG}}$ が $120 \mathrm{mg} / \mathrm{d} l$ 以下の透析群と健常者群の $\mathrm{S}-\mathrm{Fr}$ との 間に有意の差異は認めなかった（図 4).

4. S-Fr は, PG-ST, $\overline{\mathrm{PG}}$ との間に各々 $\mathrm{r}=0.627, \mathrm{r}=$ 0.724 と有意の正の相関関係 $(\mathrm{p}<0.001)$ を認めたが, $\mathrm{PG}$ -ST に比し $\overline{\mathrm{PG}}$ との方が相関性が強かった（図 5 )。ま た, S-Fr は G. Alb, G. Hb, $\mathrm{HbA}_{1 \mathrm{c}}, \mathrm{HbA}_{1}$ と有意の正の 相関関係 $(\mathrm{p}<0.001, \mathrm{n}=46)$ を認め, 各々の相関係数が $\mathrm{r}=0.868,0.742,0.608,0.576$ であったことより, G. Alb と最も良く相関性を示すことが分かる. $\overline{\mathrm{PG}}$ が $120 \mathrm{mg} /$ $\mathrm{d} l$ 以下の群では, BUN, UA, Cr, AA, 3HB, Chol, HDL, TG と S-Fr との間に相関性は認められなかった（表 $1)$.

5. PG-ST, $\overline{\mathrm{PG}}$ ともに, S-Fr とよりも S-Fr/Alb と, また, それょりも, S-Fr/AGR との間の相関が強かった (表 2 ).

\section{考察}

糖尿病を合併している慢性腎不全透析患者の予後を向 


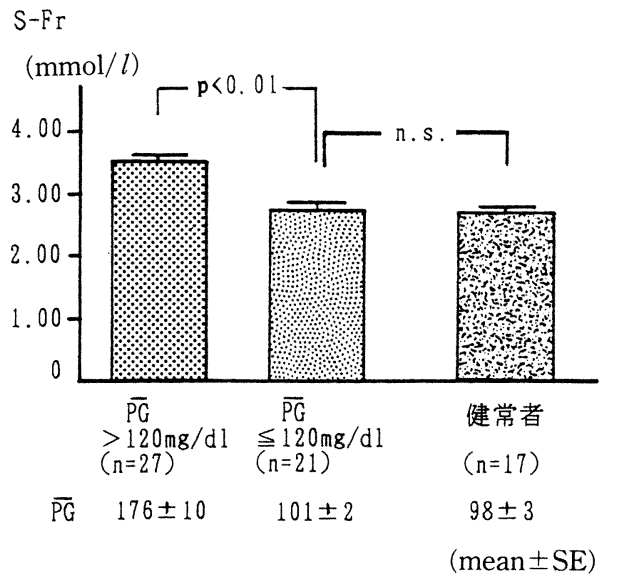

図 4 慢性腎不全透析症例 $(\overline{\mathrm{PG}}>120 \mathrm{mg} / \mathrm{d} l$ 群, $\overline{\mathrm{PG}} \leqq 120 \mathrm{mg} / \mathrm{d} l$ 群) と健常者における血清 フルクトサミン值 $(\mathrm{S}-\mathrm{Fr})$ の比較

( $\overline{\mathrm{PG}}$ : 過去 2 週間の平均透析前血糖值)

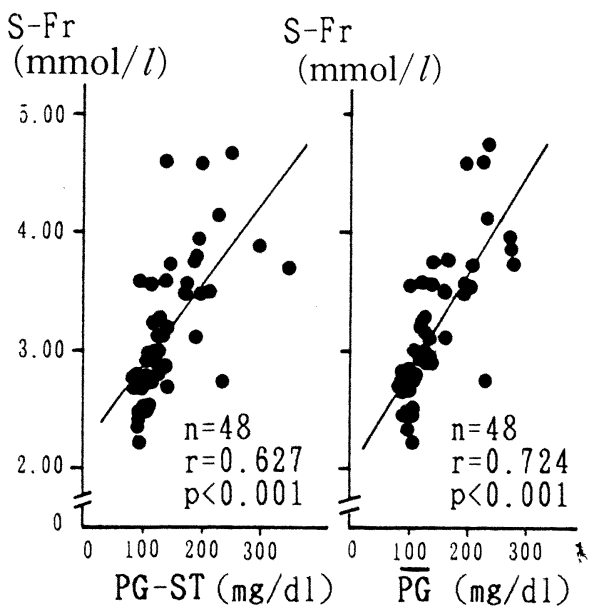

図 5 血清フルクトサミン值 (S-Fr) と透析前血 糖值 (PG-ST, $\overline{\mathrm{PG}}$ ) との相関関係 (PG-ST : S-Fr と同時測定された血糖値, $\overline{\mathrm{PG}}$ : 過去 2 週間の平均透析前血糖值)
上させる上で，糖尿病の血糖コントロールを良好に保つ ことは重要ではあるが, 実際上, 腎での糖尿病終末段階 と同様全身的に重症である場合が多いこと, 運動や食事 に制限が加わること, 腎不全物質や代謝障害による血糖 值への悪影響, など血糖コントロールの困難なことが少 なくない. その上, 血糖值測定に加え, 血清ケトン体值7), $\mathrm{HbA}_{1}$ や $\mathrm{HbA}_{1 \mathrm{c}}{ }^{8,9)}$ などが，腎不全のない糖尿病患者で は血糖コントロールの有用な指標として用いられている のに反し，腎不全患者では未だ問題の多いところであ $3^{10,11)} . \mathrm{HbF}$ や carbamylation ${ }^{12)}$ の影響を除外しえる affinity chromatography を用いた glycated hemoglobin (G. $\mathrm{Hb})$ の測定は $\mathrm{HbA}_{1}, \mathrm{HbA}_{1 \mathrm{c}}$ に比し, 透析症例 における血糖コントロール状態の指標としてはより一層 有用な方法と考えられるものの ${ }^{13)}$, 短縮された赤血球寿 命の影響からは免れえない. 今回検討された Fr の長期 (過去 2 週間)における血糖コントロール状態の指標とし ての信頼性も, 慢性腎不全透析症例における蛋白代謝, 即ち, アルブミンやグロブリンの寿命や腎不全物質など の影響を考慮せねばならない.さらに，一回の血液透析 の過程が Fr に及㴗す影響を考える上で, 抗凝固剤 heparin の影響も検索する必要がある.

抗凝固剤である heparin や EDTA-2Na を用いた P -Fr が S-Fr に比し低值を示したことや, heparin を含 む血液の EDTA-2Na 採血により一層 Fr が低下したこ とより, 透析後の Fr は除水により濃度が増加している ことが考えられるにもかかわらず, 透析前後における Fr に差異が認められなかった（図 2 ) のは, 透析中に添加 されたheparin の影響により, 測定法上, 透析後の Fr の
低下を呈したことがその一因と思われる，従って，一回 の血液透析過程が Fr 測定に及ぼす影響としては heparin の関与が大きいものと考える.

また，1) 非糖尿病性腎不全に比し糖尿病性腎症の $\mathrm{Fr}$ が高值 (図 3), 2 ) $\overline{\mathrm{PG}}$ が $120 \mathrm{mg} / \mathrm{d} l$ 以下の透析群に比 し $120 \mathrm{mg} / \mathrm{d} l$ 以上の群の $\mathrm{Fr}$ が高值（図 4), 3) S-Fr が PG-ST に比し $\overline{\mathrm{PG}}$ と相関が強かったこと（図 5 ), 4 ) S-Fr が長期間の血糖コントロール状態を表す他の指 標である G. Alb ${ }^{14)}$ や $\mathrm{G} . \mathrm{Hb}^{15)}$ と強(相関性を示したこ と,などより慢性腎不全透析症例における Fr の測定は 長期的（過去 2 週間）な血糖コントロール状態の指標と して有用であると考える。

対象症例のほとんどが無尿または乏尿のため, 低い Fr を示すネフローゼ症候群 ${ }^{2)}$ のごとく蛋白の岥失が急激で はなかったこと, また, 図 4 に示すごとく, 健常者群と $\overline{\mathrm{PG}}$ が $120 \mathrm{mg} / \mathrm{d} l$ 以下（血糖值が健常者と同程度）の透 析群との間に Fr の差異がなかったことより, 非透析に 比し透析症例の蛋白の turnover に著名な差異がないか, または，その turnover の元進による Fr の低下を腎不 全物質の付加により見掛け上補っているのかもしれな い. しかし, S-Fr が BUN, UA, Cr と相関性を示さな かったこと（表 1）より, 腎不全症例にみられる $\mathrm{Hb}$ へ の carbamylation ${ }^{12)}$ と同一の反応や腎不全物質の付加 が蛋白に生じているとしても Hb の場合に比べその短い turnover の故に Frへのそれらの影響はより少ないもの と思われる。

実際の臨床検査上, 手間は倍加するものの, 過去 2 週 間の血糖コントロール状態の指標として S-Fr に比し, 
表 $1 \overline{\mathrm{PG}} \leqq 120 \mathrm{mg} / \mathrm{d} l$ の透析群における血清フル クトサミン值 $(\mathrm{S}-\mathrm{Fr})$ と尿素窒素 $(\mathrm{BUN})$ 尿酸 (UA), クレアチニン $(\mathrm{Cr})$, アセト酢酸 (AA)，3-ヒドロキシ酪酸 (3HB)，コレステ ロール (Chol), HDL-コレステロール (HDL), 中性脂肪 (TG) の各值との相関関 係.（文字上の一は過去 2 週間の平均值の項 目，他は S-Fr と同時測定の項目を示す.)

\begin{tabular}{c|c|c|c}
\hline & 例 数 & 相関係数 & 相関関係 \\
\hline $\mathrm{S}-\mathrm{Fr}$ と BUN & $\mathrm{n}=21$ & $\mathrm{r}=0.359$ & $\mathrm{n} . \mathrm{s}$. \\
$\mathrm{UA}$ & $\mathrm{n}=21$ & $\mathrm{r}=-0.056$ & $\mathrm{n} . \mathrm{s}$. \\
$\mathrm{Cr}$ & $\mathrm{n}=21$ & $\mathrm{r}=-0.135$ & $\mathrm{n} . \mathrm{s}$. \\
$\overline{\mathrm{BUN}}$ & $\mathrm{n}=21$ & $\mathrm{r}=0.271$ & $\mathrm{n} . \mathrm{s}$. \\
$\overline{\mathrm{UA}}$ & $\mathrm{n}=21$ & $\mathrm{r}=-0.027$ & $\mathrm{n} . \mathrm{s}$. \\
$\overline{\mathrm{Cr}}$ & $\mathrm{n}=21$ & $\mathrm{r}=-0.200$ & $\mathrm{n} . \mathrm{s}$. \\
$\mathrm{AA}$ & $\mathrm{n}=21$ & $\mathrm{r}=0.148$ & $\mathrm{n} . \mathrm{s}$. \\
$3 \mathrm{HB}$ & $\mathrm{n}=21$ & $\mathrm{r}=-0.287$ & $\mathrm{n} . \mathrm{s}$. \\
$\mathrm{Chol}$ & $\mathrm{n}=10$ & $\mathrm{r}=-0.152$ & $\mathrm{n} . \mathrm{s}$. \\
$\mathrm{HDL}$ & $\mathrm{n}=10$ & $\mathrm{r}=0.075$ & $\mathrm{n} . \mathrm{s}$. \\
$\mathrm{TG}$ & $\mathrm{n}=10$ & $\mathrm{r}=-0.266$ & $\mathrm{n} . \mathrm{s}$. \\
\hline
\end{tabular}

(n.s. ; not significant)

$\mathrm{S}-\mathrm{Fr}$ を総蛋白の $\mathrm{A} / \mathrm{G}$ ratio により除す (S-Fr/AGR) ことにより, 一層, 血糖值との相関性が密になることが 示唆された（表 2 ）が，これは Fr として一括して測定 される糖化アルブミン，糖化グロブリンの代謝速度の差 や各々における糖化の程度の差を総蛋白の $\mathrm{A} / \mathrm{G}$ ratio が良く反映しているためかもしれない。しかし，今回の 対象例における総蛋白值, アルブミン值は, 前述のごと く, 各々 $5.9 \mathrm{~g} / \mathrm{d} l, 3.3 \mathrm{~g} / \mathrm{d} l$ 以上に扔ける検討例であり, それ以下の場合での解釈には注意を要するものと思われ る.

\section{結論}

糖尿病患者を含む慢性腎不全透析例において, Fr の測 定は過去 2 週間の長期的な血糖コントロール状態の指標 として有用と考えられるが, 透析後の Fr の解釈には血 液透析中に用いられる heparin の影響を考慮せねばなら ない。また, S-Fr を総蛋白の $\mathrm{A} / \mathrm{G}$ ratioにより除した 補正值 (S-Fr/AGR) は, S-Fr に比し過去 2 週間の平均 透析前血糖値とより一層強い相関性を示した。

本論文の要旨は第 33 回日本透析療法学会総会において発 表した.

\section{文献}

1) Johnson RN, Metcalf PA, Baker JR : Fructosamine : A new approach to the estimation of serum glycosylprotein. An index of diabetic
表 2 血糖值 (PG-ST, $\overline{\mathrm{PG}}-1 \mathrm{~W}, \overline{\mathrm{PG}})$ と血清フルク トサミン值 $(\mathrm{S}-\mathrm{Fr})$ ，またはその補正值 ( $\mathrm{S}-\mathrm{Fr} /$ Pro, S-Fr/Alb, S-Fr/AGR) との間の相関に おける相関係数 ( $\mathrm{r}$ ) の比較. (PG-ST ; S-Fr と同時測定された血糖值, $\overline{\mathrm{PG}}-1 \mathrm{~W}, \overline{\mathrm{PG}}$; 過去 1,2 週間の平均透析前血糖值. Pro；総蛋白 值, Alb ; アルブミン值, AGR ; 総蛋白の A/ G ratio)

\begin{tabular}{l|c|c|c}
\hline & PG-ST & $\overline{\mathrm{PG}}-\mathrm{lW}$ & $\overline{\mathrm{PG}}$ \\
\hline & $\mathrm{n}=38$ & $\mathrm{n}=16$ & $\mathrm{n}=38$ \\
\hline $\mathrm{S}-\mathrm{Fr}$ & 0.584 & 0.659 & 0.695 \\
$\mathrm{~S}-\mathrm{Fr} /$ Pro & 0.522 & 0.576 & 0.626 \\
$\mathrm{~S}-\mathrm{Fr} /$ Alb & 0.612 & 0.752 & 0.734 \\
S-Fr/AGR & 0.630 & 0.819 & 0.742 \\
\hline
\end{tabular}

control. Clin Chim Acta $127: 87-95,1982$

2) Baker JR, O' connor JP, Metcalf PA, Lawson MR, Johnson RN : Clinical usefulness of estimation of serum fructosamine concentration as a screening test for diabetes mellitus. Br Med J 287 : 863-867, 1983

3) Baker JR, Metcalf PA, Johnson RN, Newman D, Rietz $\mathrm{P}$ : Use of protein-based standards in automated colorimetric determinations of fructosamine in serum. Clin Chem $31: 1550-1554$, 1985

4) 中 恵一, 下条信雄, 北橋 繁, 佐伯成子, 平井幹 男, 奥田 清：血漿糖化蛋白・フルクトサミン測定 に関する基礎的ならびに臨床的検討. 臨床検査 31 ： 679-682, 1987

5）倉八博之, 森寺邦三郎, 石原 隆, 早稲田則雄, 笠 倉新平, 五十嵐哲也, 真坂美智子, 岩丸 博: 糖尿 病者における血清フルクトサミン值の臨床的意義. 糖尿病 $30: 987-993,1987$

6) Bessho H, Nanjo K, Nomura Y, Hirayama J, Sasaki H, Ohoshi T, Kuriyama S, Satogami E, Kondo M, Sanke T, Miyamura K : Clinical usefulness of measurement of fructosamine concentration as an index for the plasma glucose control in diabetic patients. In : Best approach to the ideal therapy of diabetes mellitus, edited by Shigeta Y : p 559-562, Excerpta Medica ICS 754, Amsterdam, 1987

7) Harano Y, Kosugi K, Hyosu T, Suzuki M, Hidaka H, Kashiwagi A, Uno S, Shigeta Y : Ketone bodies as markers for Type 1 (insulin-dependent) 
diabetes and their value in the monitoring of diabetic control. Diabetologia $26: 343-348,1984$

8) Gabbay KH, Hasty K, Breslow JL, Ellison RC, Bunn HF, Gallop PM : Glycosylated hemoglobins and long-term blood glucose control in diabetes mellitus. J Clin Endocrinol Metab 44 : 859-864, 1977

9) Koenig RJ, Peterson CM, Jones RL, Saudek C, Lehrman M, Cerami A : Correlation of glucose regulation and hemoglobin $A_{1 c}$ in diabetes mellitus. N Eng J Med 295 : 417-420, 1976

10) Casparie AF, Miedema $K$ : Glycosylated hemoglobin in diabetes and renal failure. Lancet ii : 758-759, 1977

11）野村佳成, 南條輝志男, 宮野元成, 坂本健一, 岡井 一彦, 兽和亮一, 栗山茂司, 菊岡弘芳, 里神永一, 木村 茂, 古田浩二, 宮村 敬: 慢性腎不全透析症 例における $\mathrm{HbA}_{1}$ 值（第 1 報）一糖尿病性腎症にお ける透析療法の影響一：透析会誌 $17: 153-158$,
1984

12) Flückiger R, Harmon W, Meier W, Loo S, Gabbay $\mathrm{KH}:$ Hemoglobin carbamylation in uremia. N Eng J Med 304 : 823-827, 1981

13）野村佳成, 南條輝志男, 栗山茂司, 宮野元成, 三家 登喜夫, 坂本健一, 岡井一彦, 曽和亮一, 古田浩二, 宮村 敬, 阿部富弥, 柏井利彦: 慢性腎不全透析症 例における glycosylated hemoglobin 值一affinity chromatography 法による検討一。透析会誌 18 : 197-201, 1985

14) Guthrow CE, Morris MA, Day JF, Thorpe SR, Baynes JW : Enhanced nonenzymatic glucosylation of human serum albumin in diabetes mellitus. Proc Natl Acad Sci USA 76 : 4258-4261, 1979

15) Yue DK, Mclennan S, Church DB, Turtle JR : The measurement of glycosylated hemoglobin in man and animals by aminophenylboronic acid affinity chromatography. Diabetes $31: 701-705$, 1982 